\title{
IMPLIKASI PENERAPAN PAIKEM UNTUK MENINGKATKAN PENGATAHUAN ALKITAB SMGT JEMAAT KOMBA KLASIS KESU' TALULOLO
}

Oleh:

\author{
Betzi Patanduk \\ Institut Agama Kristen Negeri Toraja \\ Email: bpatanduk@gmail.com
}

\begin{abstract}
ABSTRAK _ Pada zaman global saat ini anak-anak sekolah minggu sebagai generasi penerus dalam gereja memiliki ciri khas yang perlu mendapatkan perhatian dalam hal kebutuhan rohaninya. Sekolah Minggu khususnya Sekolah Minggu Gereja Toraja (SMGT) masa kini kurang memiliki pengetahuan yang cukup mendalam terkait isi Alkitab, bukan karena pengetahuannya yang kurang, akan tetapi dikarenakan tidak adanya motivasi untuk belajar. Pendekatan Aktif, Inovatif, Kreatif, Efektif dan Menyenangkan (PAIKEM) merupakan salah satu model atau pendekatan pembelajaran yang menekankan agar dalam pembelajaran anak-anak sebagai subjek yang aktif. Dalam pendekatan ini, anak-anak berperan aktif mengembangkan keterampilan, sikap dan pemahaman dengan penekanan pada belajar sambil bekerja, sementara pelayan menggunakan berbagai sumber dan alat bantu belajar. Makalah ini bertujuan untuk mengetahui pengetahuan Alkitab anak kelas kecil SMGT Jemaat Komba Klasis Kesu' Tallulolo dengan menggunakan metode PAIKEM.
\end{abstract}




\section{BAB I \\ PENDAHULUAN}

\section{A. Latar belakang masalah}

Sekolah minggu merupakan kegiatan bersekolah yang diadakan pada hari Minggu di gereja yang mengajarkan pelajaran keagamaan. Sekolah minggu adalah bagian penting dalam hidup pribadi anak dan turut membentuk diri anak seutuhnya. Pada umumnya sekolah minggulah yang memegang peranan penting dalam menyampaikan pendidikan kristiani kepada anak-anak. Disamping itu orang tua turut mendukung mengadakan berbagai kegiatan pembinaan yang tujuan utamanya menolong anakanak. Sekolah minggu mengupayakan berbagai macam kegiatan dengan berbagai cara, agar anak-anak menjadi lebih mudah dalam menyesuaikan diri, oleh karena itu diperlukan pelayan sekolah minggu untuk membuat anak-anak merasa aman dan gembira tanpa rasa takut didalam mengembangkan imannya. Pelayan sekolah minggu terpanggil untuk menjadi akrab dengan anak-anak dan menjadi bagian dari hidup mereka.

Salah satu tugas panggilan dari pelayan sekolah minggu adalah menolong anakanak kecil dalam mengembangkan dirinya agar mampu menjadi pribadi yang bertanggung jawab serta mengalami kasih Kristus melalui proses tersebut. Dalam pembelajaran motivasi merupakan salah satu aspek dinamis yang sangat penting. Seringkali anak-anak yang tingkat kecerdasannya kurang atau rendah bukan hanya disebabkan oleh kemampuannya yang kurang, akan tetapi dikarenakan tidak adanya motivasi untuk belajar sehingga ia tidak berusaha untuk mengumpulkan segala kemampuannya. Ini menjadi masalah yang cukup serius dalam hal pembelajaran. Bagaimana motivasi belajar anak-anak akan terbangun jika strategi mengajar yang digunakan oleh guru tidak kreatif, tidak menarik, dan tidak inovatif. Dalam kaitannya dalam mengajar anak sekolah minggu kelas kecil, kecenderungan yang ada pada saat ini, motivasi peserta didik dalam belajar Alkitab masih perlu ditingkatkan. Masih banyak ditemui bahwa minat baca, menulis, dan berkarya dalam hal belajar Alkitab hanya terjadi pada sebagian kecil peserta didik. Apabila permasalah ini tidak segera diatasi tentu akan menimbulkan permasalah, dengan kata lain bagaimana hasil belajar anak akan baik, jika proses mengajarnya atau membimbingnya bermasalah, dan anak tidak termotivasi untuk belajar.

Pendekatan Aktif, Inovatif, Kreatif, Efektif dan Menyenangkan merupakan salah satu model atau pendekatan pembelajaran yang menekankan agar dalam pembelajaran 
anak-anak sebagai subjek yang aktif. Dengan belajar aktif, inovatif, kreatif, efektif dan menyenangkan, murid diharapkan mampu membangun makna yang berbeda. Dalam pendekatan ini, anak-anak berperan aktif mengembangkan keterampilan, sikap dan pemahaman dengan penekanan pada belajar sambil bekerja, sementara pelayan menggunakan berbagai sumber dan alat bantu belajar. Dalam memahami Pendekatan Aktif, Inovatif, Kreatif, Efektif dan Menyenangkan di ketahui bahwa anak-anak harus berperan aktif dalam pembelajaran. Namun sebaliknya dalam objek penelitian penulis, yang mengambil objek penelitian di Jemaat Komba klasis Kesu' Tallulolo khususnya di kelas anak kecil menemukan bahwa kenyataan yang terjadi tidak sesuai dengan apa yang seharusnya terjadi. Pendektan aktif, inovatif. kreatif, efektif dan menyenangkan tidak diterapkan sama sekali. Bahkan yang sering diterapkan adalah model atau metode ceramah, sehingga apabila diperhatikan anak-anak begitu jenuh dalam mendengarkan firman.

Berdasarkan latar belakang yang telah disebutkan sebelumnya, penulis bermaksud membahas tentang pelaksanaan metode PAIKEM dapat dilaksanakan dengan baik untuk meningkatkan pengetahuan Alkitab anak sekolah minggu.

\section{B. Rumusan masalah}

Bagaimana cara pelayan sekolah minggu meningkatkan pengetahuan Alkitab anak kelas kecil SMGT Jemaat Komba Klasis Kesu' Tallulolo dengan menggunakan metode PAIKEM?

\section{Tujuan}

Untuk mengetahui pengetahuan Alkitab anak kelas kecil SMGT Jemaat Komba Klasis Kesu' Tallulolo dengan menggunakan metode PAIKEM.

\section{Manfaat}

Membantu setiap pembaca khususnya kepada orang tua dan guru sekolah minggu kelas kecil mengetahui bagaimana pentingnya membangun motivasi anak dalam mengikuti ibadah dengan menggunakan pendekatan aktif, inovatif, kreatif, efektif dan menyenangkan 


\section{BAB II}

ISI

\section{A. Sekolah Minggu}

Kegiatan atau pelayanan Sekolah Minggu merupakan pelayanan yang sangat penting. Jika sebuah bangunan membutuhkan pondasi yang kuat untuk menunjang bangunan. Demikian pula hidup manusia membutuhkan sebuah pondasi yang kuat. Bagi orang Kristen, untuk memiliki pondasi iman yang kuat maka dibutuhkan sebuah pendidikan yang sedini mungkin untuk meletakkan dasar yang kokoh. Sekolah Minggu menjadi tempat bagi gereja untuk meletakkan pondasi iman yang kuat pada setiap orang Kristen. Tidak dapat dipungkiri banyaknya remaja Kristen yang hidup jauh dari Tuhan disebabkan oleh karena tidak ada dasar iman yang kokoh. Oleh sebab itu pelayanan Sekolah Minggu harus dijalankan dengan baik dan maksimal. Pelayanan sekolah minggu membutuhkan sebuah kesanggupan hati setiap guru untuk menjalankan pelayanan ini yang bisa membangun motivasi anak dalam mengikuti peribadahan di gereja dan anak menjadi semakin tahu dan memahami akan firman Tuhan.

\section{B. Pengertia PAIKEM}

PAIKEM adalah pendekatan mengajar digunakan bersama metode tertentu dan pelbagai media pengajaran yang disertai penataan lingkungan sedemikian rupa agar proses pembelajaran menjadi aktif, inovatif, kreatif, efektif, dan menyenangkan. ${ }^{1}$

Dalam pembelajaran aktif, inovatif, kreatif, efektif dan menyenangkan juga merupakan sebuah pendekatan pembelajaran yang memungkinkan siswa mengerjakan kegiatan yang beraneka ragam untuk mengembangkan keterampilan dan pemahaman dengan penekanan kepada belajar sambil bekerja, sementara guru menggunakan berbagai sumber dan alat bantu belajar termasuk memanfaatkan lingkungan supaya pembelajaran lebih menarik, menyenangkan dan efektif dan relevan bagi siswa. PAIKEM dilatarbelakangi oleh kenyataan bahwa pembelajaran konvensional atau secara umum dinilai menjemukan, kurang menarik bagi anakanak sehingga berakibat kurang optimal dalam penguasaan pembelajaran bagi anak-anak. Pendekatan PAIKEM menekankan pada tahap permainan yang memungkinkan dapat membuat anak-anak senang dalam belajar maka proses

\footnotetext{
${ }^{1}$ Dr. H. Darmadi, S.Ag., M.M., MM.Pd., M.Si, Optimalisasi Strategi Pembelajaran (Bogor: Guepedia Publisher, 2018) 248.
} 
belajar mengajar sangat diperlukan strategi pembelajaran yang baik dan cocok dan menarik bagi anak-anak. Dalam model belajar ini guru dituntut untuk menciptakan suasana, sehingga siswa aktif bertanya, memberi tanggapan, mengungkapkan ide, dan mengungkapkan gagasan.

Guru aktif memantau kegiatan belajar, memberi umpan balik, mengajukan pertanyaan menantang dan mempertanyakan gagasan anak sehingga ia akan terangsang motivasinya untuk belajar. Hal yang paling utama yang menjadi keaktifan anak-anak adalah munculnya rasa ingin tahu, ketertarikan dan minat siswa terhadap hala yang sedang dipelajari. Untuk itu, melalui berbagai teknik dan metode, guru harus berusaha sebisa mungkin untuk menciptakan suasana sedemikian rupa guna memicu rasa kepenasaran anak-anak aktif bertanya, mempertanyakan mempertanyakan, mengemukakan gagasannya. Inovatif artinya pembelajaran dapat dilakukan dengan cara mengadaptasi model-model pembelajaran menyenangkan yang bisa membuat anak-anak terbebas dari kejenuhan-kejenuhan pembelajaran. Kreatif diartikan guru memberikan variasi dalam kegiatan belajar mengajar dan membuat alat bantu balajar, bahkan menciptakan teknik-teknik mengajar tertentu sesuai dengan tingkat kemampuan anak-anak. Anak-anak akan kreatif bila diberi kesempatan merancang, membuat sesuatu, menuliskan ide atau gagasannya. Berpikir kreatif adalah sebuah kebiasaan dari pikiran yang dilatih dengan menghidupkan imajinasi, mengungkapkan kemungkinan-kemungkinan aktivitas mental seperti mengajukan pertanyaan, mempertimbangkan informasi baru.

Efektif diartikan sebagai ketercapaian suatu tujuan merupakan pijakan utama suatu rancangan pembelajaran aktif, kreatif akan lebih efektif untuk mewujudkan tujuan, siswa akan termotivasi untuk belajar. Disamping itu, yang juga penting adalah banyaknya pengalaman dan hal hal baru yang diperoleh anak-anak. Guru pun diharapkan memperoleh pengalaman baru sebagai hasil interaksi dua arah dengan anak-anak yang diajar. Menyenangkan diartikan sebagai suasana penuh keceriaan, belajar mengajar yang semarak terkondisi untuk terus berlanjut, ekspresif, dan mendorong pemusatan perhatian anak-anak terhadap belajar dan yang paling utama tidak membosankan bagi anak-anak. Agar menyenangkan, diperlukan penegasan memberi pengakuan kerja kerasnya dengan tepuk tangan, dan pemberian hadiah. Ini akan memotivasi anak-anak untuk belajar khususya matematika. Kegiatan belajar yang aktif, kreatif, dan menyenangkan harus tetap 
bersandar pada tujuan yang dicapai. Salah satu upaya menciptakan pembelajaran yang menyenangkan adalah dengan menggunakan permainan edukatif atau belajar sambil bermain. Melalui keterlibatan dalam permainan, mereka dapat mengembangkan dirinya serta mulai memahami perannya dalam kelompok teman sebayanya, yang akan sangat bermanfaat untuk memahami dan melakukan perannya dalam lingkungan sekitarnya setelah beranjak dewasa. Terdapat satu prinsip utama dalam pemilihan permainan edukatif ini dalam pembelajaran, yakni harus terdapat keselarasan dan kesinambungan antara aspek menyenangkan dengan aspek pencapaian tujuan pembelajaan.

PAIKEM tidak akan berhasil jika guru tidak memiliki kepribadian yang baik. Guru harus memiliki selera humor, mau menerima kritik, menganngap siswa sebagai pribadi yang potensial dan miliki kelebihan yang unik, dan mau belajar dari siapa pun atau kemampuan mendengar dan memahami orang lain.

\section{Karakteristik PAIKEM}

1. Berpusat pada siswa (student-centered), dalam pendekatan ini anak-anak menjadi pelaku aktif dalam kegiatan belajar, dimana dalam belajar menggunakan bebarbagai sumber, memungkinkan anak-anak belajar dengan senang hati dan menikmati setiap prosesnya, baik di dalam maupun di luar kelas.

2. Belajar yang menyenangkan (joyfull learning);

3. Belajar yang berorientasi pada tercapainya kemampuan tertentu (competency basedlearning);

4. Belajar secara tuntas (mastery learning);

5. Belajar secara berkesinambungan (continuous learning);

6. Belajar sesuai dengan ke-kini-an dan kedisini-an (contextual learning).

\section{Hal-hal yang perlu diperhatikan dalam pelaksaan PAIKEM}

1. Memahami sifat yang dimiliki siswa

Pada dasarnya anak memiliki imajinasi dan sifat ingin tahu. Semua anak terlahir dengan membawa dua potensi ini. ${ }^{2}$

Keduanya merupakan modal dasar bagi berkembangnya sikap/pikiran kritis dan kreatif. Oleh karenanya, kegiatan pembelajaran perlu dijadikan lahan yang kita olah agar menjadi tempat yang subur bagi perkembangan kedua

\footnotetext{
${ }^{2}$ M. Anas, M.Pdl, Mengenal Metodologi Pembelajaran ( Jawa Timur: CV. Pustaka Hulwa, 2014), 76.
} 
potensi. Dalam memahami sifat yang dimiliki oleh anak tersebut perlu juga memahami perkembangan kecerdasannya. Guru harus menyadari, berapa tahun ia menguasai bahan pengajaran yang ia sampaikan. Kemudian anak-anak, sejak kapan ia memahaminya. Sehingga wajar jika anak belum bisa. Selanjutnya guru harus tahu usia berapa anak-anak yang diajar sekarang. Kemudian melihat pada usia sekian tingkat kecerdasan apa anak ini berada. Sehingga dalam berbicara dan mengajar ia memakai metode yang tepat.

2. Mengenal anak secara perorangan

Semua anak berasal dari lingkungan keluarga yang bervariasi dan memiliki kemampuan yang berbeda. Dalam PAIKEM perbedaan individual perlu diperhatikan dan harus tercermin dalam kegiatan pembelajaran. Semua anak dalam kegiatan belajar tidak selalu mengerjakan kegiatan yang sama, melainkan berbeda sesuai dengan kecepatan belajarnya. Anak yang memiliki kemampuan lebih dapat dimanfaatkan untuk membantu temannya yang kurang.

3. Mengembangkan kemampuan berpikir kritis, kreatif, dan kemampuan memecahkan masalah

Pada dasrnya belajar yang baik adalah memecahkan masalah, karena dalam belajar sesungguhnya kita menghadapkan siswa pada masalah. Hal ini memerlukan kemampuan berpikir kritis dan kreatif. Kristis untuk menganalisis masalah dan kreatif untuk melahirkan alternatife pemecahan masalah.

4. Mengembangkan ruangan sebagai lingkungan belajar yang menarik

Ruang belajar yang menarik merupakan hal yang sangat disarankan dalam PAIKEM. Hasil pekerjaan anak sebaiknya dipajangkan untuk memenuhi ruang kelas. Selain itu, hasil pekerjaan yang dipajangkan diharapkan memotivasi anak untuk bekerja lebih baik dan menimbulkan inspirasi bagi siswa lain.

5. Memanfaatkan lingkungan sebagai sumber belajar

Lingkungan merupakan sumber yang sarat dengan bahan belajar anak. Lingkungan dapat berperan sebagai media belajar dan objek kajian (sumber belajar). Penggunaan lingkungan sebagai sumber belajar sering membuat siswa merasa senang dalam belajar. 


\section{E. Kelebihan dan kelemahan model PAIKEM}

1. Kelebihan

Dengan model PAIKEM guru tidak hanya monoton saja dalam menyampaikan pelajaran, namun dapat bervariatif dan lebih kreatif dalam menampilkan dalam menampilkan berbagai hal ajaran kepada anak. Begitu pula dengan keadaan anak akan lebih enjoy dalam menangkap suatu ajaran, tidak mudah bosan dan suntuk. Anak selalu termotivasi akan lebih giat untuk meraih prestasi yang cerah, gemilang, dan penuh antusias.

2. Kelemahan

Program ini mengharuskan seorang guru untuk berperan aktif, proaktif dan kreatif dalam mencari dan merancang media/bahan ajar alternative yang mudah, murah dan sederhana, namun tetap relevan dengan tema yang sedang dipelajari. Penggunaan perangkat multimedia seperti ICT sungguh sangat ideal, tetapi tidak semua lembaga sekolah ataupu gereja mampu mengaksesnya. 


\section{BAB III}

PENUTUP

\section{A. Kesimpulan}

Berdasarkan hasil penelitian yang dilakukan mengenai hasil belajar Alkitab SMGT Jemaat Komba Klasis Kesu' Tallulolo, melalui implementasi PAIKEM secara keseluruhan menunjukkan hasil positif dan baik. Dengan menggunakan penerapan PAIKEM dalam mengajar anak-anak, mereka memiliki motivasi yang yang baik dalam mendengarkan cerita yang disampaikan. Hal ini dikarenakan metode PAIKEM dikemas secara menarik dan bervariasi sehingga membuat anak-anak merasa senang dan tidak merasa bosan ketika proses ibadah berlangsung.

\section{B. Saran}

Proses menyampaikan firman atau cerita Alkitab dengan menerapkan metode PAIKEM dapat meningkatkan motivasi anak dalam mengikuti ibadah. Berdasarkan hal tersebut, maka disarankan bagi setiap guru sekolah minggu untuk menggunakan metode PAIKEM dalam proses menyampaikan firman atau cerita Alkitab. Bagi gereja diharapkan dapat memberikan dukungan terhadap pelaksanaan PAIKEM sehingga proses ibadah di sekolah minggu dapat terlaksana dengan baik. Dikarenakan untuk dapat mencapai tujuan dan keberhasilan dalam menyampaikan firman atau cerita Alkitab diperlukan dukungan dari semua pihak, sehingga dapat mencapai kualitas pengajaran yang lebih baik. 


\section{DAFTAR PUSTAKA}

Anas, M, 2014. Mengenal Metode Pembelajaran. Jawa Timur: CV Pustaka Hulwa.

Darmadi, H, 2018. Optimalisasi Strategi Pembelajaran: Inovasi Tiada Henti Meningkatkan Kualitas Proses dan Hasil Belajar Peserta Didik. Bogor: Guepedia Publisher.

Lewis, Paul, 2005. 40 Cara Mengarahkan Anak. Bandung: Kalam Hidup.

Musfah, Jejen, 2015. Manajemen Pendidikan. Jakarta: Kencana.

Panuntun, Daniel Fajar, Rinaldus Tanduklangi, Merry Adeng, and Christian Eleyazar Randalele. "Model Ibadah Sekolah Minggu Kreatif-Interaktif Bagi Generasi Alfa Di Gereja Toraja.” BIA': Jurnal Teologi dan Pendidikan Kristen Kontekstual 2, no. 2 (2019): 19-20. 